\title{
EFFECT OF WOOD GRADING ON THE MECHANICAL PROPERTIES OF GLULAM MADE OF Tectona grandis
}

\author{
Setsuo Iwakiri ${ }^{1}$, Jorge Luis Monteiro de Matos ${ }^{1}$, José Guilherme Prata ${ }^{1}$, Rosilani Trianoski ${ }^{1}$, Carlos \\ Frederico Alice Parchen ${ }^{2}$, Vinicius Gomes de Castro ${ }^{2}$, Viviane Teixeira Iwakiri ${ }^{3}$ \\ ${ }^{1}$ Forest Engineer, Dr., Forest Engineering and Technology Dep., UFPR, Curitiba, PR, Brazil - setsuo@ufpr.br; jmatos@ufpr.br; \\ prata@ufpr.br; rosilani@ufpr.br \\ ${ }^{2}$ Civil Engineer, Forest Engineer, PhD candidate in Forest Engineering, UFPR, Curitiba, PR, Brazil - parchen@ufpr.br; \\ vinnie.castro@gmail.com. \\ ${ }^{3}$ Architect, MSc., Student in Architecture and Urbanism, UFSC, Florianopolis, SC, Brazil - viviane_iwakiri@gmail.com
}

Received for publication 28/03/2013 - Accepted for publication 20/03/2014

\begin{abstract}
This study aimed to evaluate the influence of the wood grading by the method of stress waves in the mechanical properties of glued laminated beams (glulam) made of Tectona grandis. A total of 87 battens with dimensions of $25 \times 75 \times 3.000 \mathrm{~mm}$ were obtained from the 5 trees and 3 logs per tree, in the axial direction (base, middle and top) and radial (pith - bark). After drying, the battens were planed to the final dimensions of $20 \times 60 \times 2200 \mathrm{~mm}$, and then subjected to grading by application of stress waves. Were defined three classes of dynamic modulus of elasticity (DMOE) and the beams were composed with five pre-classified battens. The beams were bonded with resorcinol-phenol-formaldehyde resin, with a weight of $350 \mathrm{~g} / \mathrm{m}^{2}$ (double surface), specific pressure of $1.0 \mathrm{MPa}$ and pressing time of 8 hours. The grading process of the battens using the stress wave method showed to be efficient for the composition of beams. The results of static bend and glue line shear strength tests indicated the technical feasibility of using wood of Tectona grandis for the production of glued laminated beams.

Keywords: Wood bonding; structural wood; resorcinol-phenol-formaldehyde resin.
\end{abstract}

\section{Resumo}

Influência da classificação das lamelas nas propriedades mecânicas de vigas laminadas coladas de Tectona grandis. Este trabalho teve como objetivo avaliar a influência da classificação da madeira pelo método de ondas de tensão nas propriedades mecânicas de vigas laminadas coladas de Tectona grandis. Um total de 87 lamelas com dimensões de $25 \times 75$ x $3.000 \mathrm{~mm}$ foram obtidas a partir da amostragem de 5 árvores e 3 toras / árvore, nas direções axial (base, meio e topo) e radial (medula - casca). Após a secagem, as lamelas foram aplainadas para as dimensões finais de $20 \times 60 \times 2.200 \mathrm{~mm}$, sendo a seguir submetidas à classificação por meio de aplicação de ondas de tensão. Foram estabelecidas três classes de módulo de elasticidade dinâmico (MOEd) e as vigas foram compostas de cinco lamelas pré-classificadas. As vigas foram coladas com resina resorcina-fenol-formaldeído, com gramatura de $350 \mathrm{~g} / \mathrm{m}^{2}$ (linha dupla), pressão específica de 1,0 MPa e tempo de prensagem de 8 horas. A classificação das lamelas pelo método de ondas de tensão mostrou ser eficiente para a composição das vigas. Os resultados de ensaios de flexão estática e cisalhamento da linha de cola indicaram a viabilidade técnica de uso da madeira de Tectona grandis para produção de vigas laminadas coladas.

Palavras-chave: Colagem de madeiras; estruturas de madeira; resina resorcina-fenol-formaldeído.

\section{INTRODUCTION}

Tectona grandis L.f. (Teak) is a native species to the tropical forests, naturally distributed in the Indian subcontinent and in Southeastern Asia. The forest plantings of Teak in Brazil were introduced in the 1960s, in the Municipality of Cáceres, State of Mato Grosso and today covers an area around 50 thousands ha (REVISTA DA MADEIRA (REMADE), 2009). The favorable climatic conditions, a more fertile soil and the adequate silvicultural management contributed to reduce the production cycle, from the original 80 years in the native regions, to just 25 years in the western-central and northern regions of the country. 
Teak wood is widely known in the international market, because of its technological qualities. It is considered moderately heavy, with mean density of $0.65 \mathrm{~g} / \mathrm{cm}^{3}$. The main characteristics of Teak wood are its durability, dimensional stability, natural resistance to mycelia and insects, pests and borers, design, color and lack of knots which, taken together, make of this species the most valuable hardwood in the world.

Thanks to its good properties, Teak wood can be used in various applications. In the international market, where its price is high, the use is restricted to noble applications, like: fine furniture, high quality wood frames, floors, internal and external decoration (panels, veneers, naval construction - decks of sailboats and yachts). Wood from forest plantations, with smaller diameter, generated by thinning, is mainly used as lumber and for the production of EGP glued panels, which are widely used in the fabrication of furniture, doors and internal decoration.

Widening the use of Teak, mainly of the wood obtained from the first thinning operations, for the fabrication of products with more aggregated value, would be a strategy for the valorization of this wood and an encouragement to the forest plantations of the species. Production of Teak EGP panels is already consolidating as raw matter for the production of furniture and other internal decorations. Teak wood could also be used in the production of glued laminated beams (glulam), for structural applications. Studies have been conducted assessing the use of Pine and Eucalyptus wood in the production of glulam, and those species are already being commercially used in small scale.

In the production of glulam, wood grading for the composition of the external parts increases the mechanical strength against static bending. One of the most used methods with this purpose is the stress waves method to obtain the dynamic modulus of elasticity (DMOE) and the following definition of the strength classes. Matos (1997) applied this method to the grading of Pinus taeda plywood for the production of wood veneers and obtained significant increases in the modulus of elasticity (MOE) and modulus of rupture (MOR), gluing the higher grade plywood on the external sides of the veneers. Pio (2002) used Eucalyptus grandis plywood, previously classified with stress waves, and obtained veneers with greater strength against static bending, placing higher DMOE class plywood in the external faces of the produced veneers.

Applying the same method to glulam, Cunha (2007) observed a significant increase of MOE and MOR in the products assembled with higher DMOE battens in the external layers, after having graded them through the application of stress waves. Nielsen (1998) obtained, in glulam produced with Eucalyptus spp. battens, after classification with the stress waves method, greater MOE and MOR values in the static bending conditions.

It is possible to increase the added value of Teak wood and widen its applications to the fabrication of structural beams by the use of bonding technologies and the optimized use of wood formerly classified by quality classes. To investigate this proposal of research, this work aimed to assess the influences of wood grading by the stress waves method on the mechanical properties of glulam made of Tectona grandis wood.

\section{MATERIAL AND METHODS}

This research was conducted using 18 years old wood of Tectona grandis, coming from forest plantations located in the municipality of Brasnorte, State of Mato Grosso. Five trees were collected randomly and were then sectioned to obtain three 3.0 meters long logs, identified as base, middle and top.

A board $75 \mathrm{~mm}$ thick was obtained from the central position of each log, which then were used to prepare $25 \mathrm{~mm}$ thick battens to manufacture the glulam. Specimens were extracted from the extremities of the battens to be used for the determination of the wood properties. Steps for the preparation of the described material are shown in figure 1.

The battens with nominal dimensions $25 \times 75 \times 2200 \mathrm{~mm}$ were naturally dried and acclimatized until they reached an average moisture content of $12 \%$ and were later evened out on the four sides to obtain the final dimensions of $20 \times 60 \times 2200 \mathrm{~mm}$. The process gave 87 battens which were classified through the application of stress waves using the stress wave timer device.

After classification of the battens in three classes of dynamic modulus of elasticity (C1, C2, C3), beams composed of five layers were produced, measuring $60 \times 100 \times 2200 \mathrm{~mm}$ (width, height and length), according to the experimental design shown in table 1 . 


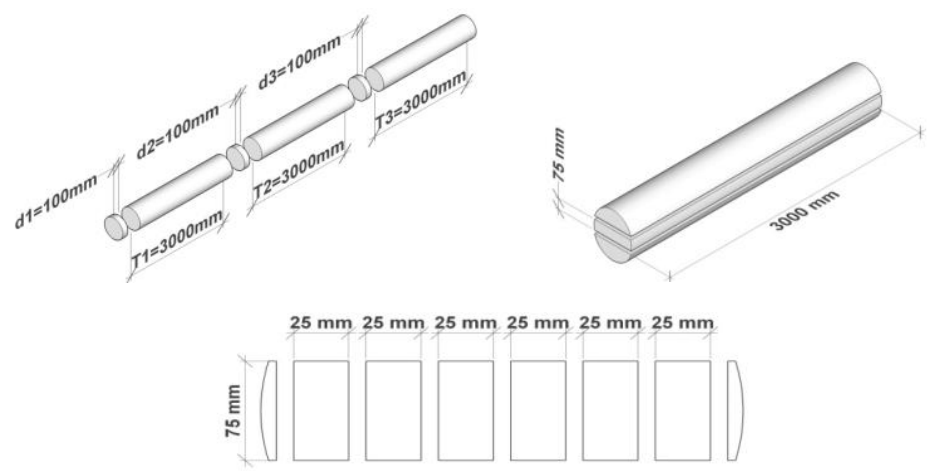

Figura 1. Esquema de obtenção das lamelas para manufatura de vigas.

Figure 1. Scheme to obtain battens for glulam manufacture.

The beams were composed of five battens, and their production followed the distribution of layers according to the DMOE classes $\mathrm{C} 1, \mathrm{C} 2$ and $\mathrm{C} 3$, for the treatments from $\mathrm{T} 1$ to $\mathrm{T} 6$, and a random distribution for the T7 treatment. Gluing was performed using phenol resorcinol formaldehyde (PRF) resin with Brookfield viscosity of $650 \mathrm{cP}$, content of solid material $55 \%$ and $\mathrm{pH} 7.0$. After mixing with the hardener (FM-316M) in a proportion of 100 parts of PRF and 20 parts of FM-316M, the adhesive was applied on one of the sides of the battens, with a glue line weight of $350 \mathrm{~g} / \mathrm{m}^{2}$. Beams were pressed with a special device with steel clamps, with a specific tool pressure of $1 \mathrm{MPa}$ and a pressing time of eight hours. Temperature variation of the environment during the processing time of the beams was from $20.5^{\circ} \mathrm{C}$ to $27.8^{\circ} \mathrm{C}$.

Tabela 1. Delineamento experimental.

Table 1. Experimental design.

\begin{tabular}{cccc}
\hline Treatment & Composition & Weight & Pressing time \\
\hline $\mathrm{T} 1-\mathrm{C} 1 / \mathrm{C} 1$ & C1-C1-C1-C1-C1 & & \\
$\mathrm{T} 2-\mathrm{C} / \mathrm{C} 2$ & $\mathrm{C} 2-\mathrm{C} 2-\mathrm{C} 2-\mathrm{C} 2-\mathrm{C} 2$ & & \\
$\mathrm{~T} 3-\mathrm{C} 3 / \mathrm{C} 3$ & $\mathrm{C} 3-\mathrm{C} 3-\mathrm{C} 3-\mathrm{C} 3-\mathrm{C} 3$ & & \\
$\mathrm{~T} 4-\mathrm{C} 1 / \mathrm{C} 3$ & $\mathrm{C} 1-\mathrm{C} 3-\mathrm{C} 3-\mathrm{C} 3-\mathrm{C} 1$ & $350 \mathrm{~g} / \mathrm{m}^{2}$ & \\
$\mathrm{~T} 5-\mathrm{C} 1 / \mathrm{C} 2$ & $\mathrm{C} 1-\mathrm{C} 2-\mathrm{C} 2-\mathrm{C} 2-\mathrm{C} 1$ & & \\
$\mathrm{~T} 6-\mathrm{C} 2 / \mathrm{C} 3$ & $\mathrm{C} 2-\mathrm{C} 3-\mathrm{C} 3-\mathrm{C} 3-\mathrm{C} 2$ & & \\
T7 & RANDOM & & \\
\hline Composition: face - internal layers - face; $\mathrm{C} 1 \cdot$ class $1 ; \mathrm{C} 2 \cdot$ class $2 \cdot \mathrm{C} 3 \cdot$ class3 &
\end{tabular}

Composition: face - internal layers - face; $\mathrm{C} 1$ : class 1 ; $\mathrm{C} 2$ : class 2; $\mathrm{C} 3$ : class3.

After pressing, beams were acclimatized in a climatic chamber at a temperature of $20 \pm 2{ }^{\circ} \mathrm{C}$ and $65 \pm 5 \%$ relative humidity until stabilization. Later, the static bending tests were performed according to the standard (AMERICAN STANDARD FOR TESTING AND MATERIALS (ASTM D-198), 1996), to determine the modulus of elasticity (MOE) and the modulus of rupture (MOR). The assessment of the glue line strength was performed through shear strength tests based on the ASTM D-3110 (1990) standard, applied to eight specimens taken from the extremities of each bonded beam.

Results of the static bending tests of the bonded beams were comparatively analyzed considering the MOE and MOR values obtained by each beam, taking into consideration that the quantity of battens was insufficient to produce enough bonded beams to have replications within the treatments. The shear strength tests results were analyzed by ANOVA and Tukey test, with a completely randomized design at $95 \%$ level of probability.

\section{RESULTS AND DISCUSSIONS}

\section{Apparent specific density of wood}

The mean values of the apparent specific density varied from $0.456 \mathrm{~g} / \mathrm{cm}^{3}$ to $0.559 \mathrm{~g} / \mathrm{cm}^{3}$ depending on the axial and radial position of the samples in the trees, and the overall mean density of the species was 
$0.519 \mathrm{~g} / \mathrm{cm}^{3}$ (Table 2). In the axial direction, the mean value obtained for the base was statistically higher than the middle section and equal to the upper part of the trees. In the radial direction, wood closer to bark presented mean value statistically lower than the value obtained in wood closer to the pith. Values found were smaller compared to some bibliographic references. Melo et al. (2006) found in Teak wood a basic specific density in the radial direction equal to $0.63 \mathrm{~g} / \mathrm{cm}^{3}$ in the inner section, $0.61 \mathrm{~g} / \mathrm{cm}^{3}$ in the middle-inner section, $0.66 \mathrm{~g} / \mathrm{cm}^{3}$ in the middle-outer section and $0.59 \mathrm{~g} / \mathrm{cm}^{3}$ in the outer section of the timber. Considering other species from forest plantations with commercial interest, Trianoski (2012) obtained, from seven species of 18 years old tropical Pines in the region of Ventania-PR, a basic specific density spanning between $0.431 \mathrm{~g} / \mathrm{cm}^{3}$ to 0.560 $\mathrm{g} / \mathrm{cm}^{3}$. Silva (2002) obtained from Eucalyptus grandis timber, aged 10, 14, 20 and 25 years, values of specific density respectively of $0.34,0.41,0.47$ and $0.42 \mathrm{~g} / \mathrm{cm}^{3}$.

Tabela 2. Resultados de massa específica aparente da madeira de Teca.

Table 2. Results of apparent density of Teak wood.

\begin{tabular}{lccc}
\hline Direction in the tree & Position in the tree & Mean $\left(\mathbf{g} / \mathbf{c m}^{\mathbf{3}}\right)$ & Overall mean $\left(\mathbf{g} / \mathbf{c m}^{\mathbf{3}}\right)$ \\
\hline Longitudinal & Base & $0,550 \mathrm{a}$ & \\
& Middle & $0,512 \mathrm{~b}$ & \\
& Top & $0,522 \mathrm{ab}$ & 0,519 \\
Radial & Pith & $0,456 \mathrm{~A}$ & \\
& Bark & $0,559 \mathrm{~B}$ & \\
\hline
\end{tabular}

\section{Classification of battens through the stress waves method}

The dynamic modulus of elasticity values (DMOE) of the 87 battens, obtained through the stress waves methods, spanned between 9,523 to 17,457 MPa. Taking into consideration the lack of information about the DMOE of Teak wood, values measured were compared to the results of some species of Pine available in the literature, since they are important species on a commercial point of view. Trianoski (2012), analyzing wood from seven species of tropical Pines reported DMOE spanning between 4,346 to 6,458 MPa, and for Pinus taeda a value of 9,671 MPa. Cunha (2007) reported DMOE from 5,000 to 11,000 MPa studying battens of Pinus taeda.

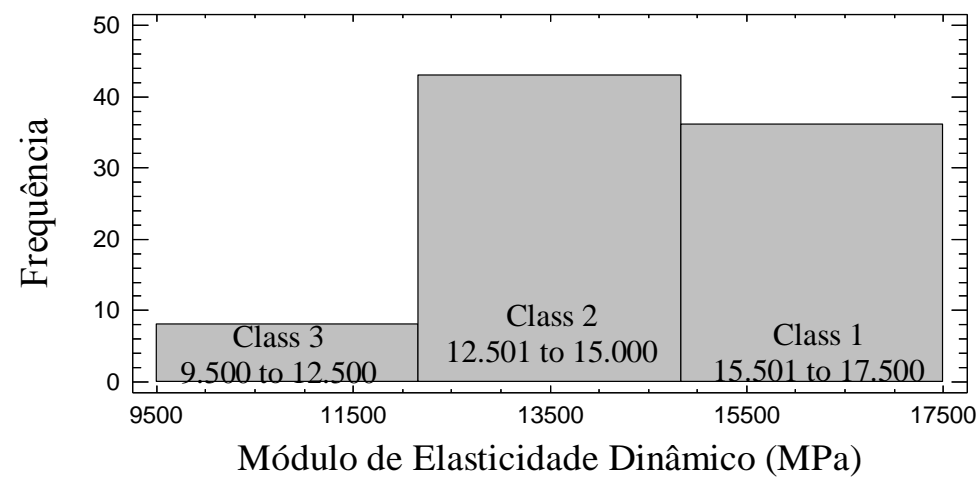

Figura 3. Histograma de frequência do MOEd das lamelas.

Figure 3. Histogram frequency of DMOE of the battens.

DMOE classes, defined basing on the frequency of the individual values of the 87 evaluated battens, are presented in figure 3. The DMOE classes were defined as follows: C3 class: from 9,500 to $12,500 \mathrm{MPa}, \mathrm{C} 2$ class: from 12,501 to $15,000 \mathrm{MPa}, \mathrm{C} 1$ class: from 15,501 to $17,500 \mathrm{MPa}$. It is evident that almost $90 \%$ of the battens were classified with the higher DMOE classes (class $\mathrm{C} 1$ and $\mathrm{C} 2$ ).

\section{Static bending strength}

In table 3 are shown the results of the apparent specific density, modulus od elasticity and modulus of rupture on static bending of the glulam beams. Values of specific density for the bonded beams spanned from $0.590 \mathrm{~g} / \mathrm{cm}^{3}$ (composition $\mathrm{C} 3 / \mathrm{C} 3$ ) to $0.655 \mathrm{~g} / \mathrm{cm}^{3}$ (composition $\mathrm{C} 1 / \mathrm{C} 1$ ) with mean 
value of $0.626 \mathrm{~g} / \mathrm{cm}^{3}$. MOE values spanned between $8,741 \mathrm{MPa}(\mathrm{C} 2 / \mathrm{C} 2)$ to $13,834 \mathrm{MPa}(\mathrm{C} 1 / \mathrm{C} 3)$, with mean value equal to $11,679 \mathrm{MPa}$. MOR values were measured between $38 \mathrm{MPa}(\mathrm{C} 3 / \mathrm{C} 3)$ to $85 \mathrm{MPa}$ $(\mathrm{C} 1 / \mathrm{C} 1)$ and with mean value of $60.3 \mathrm{MPa}$.

Compared to the reference values in the literature, Cunha (2007) reported for Pinus taeda beams, bonded with phenol resorcinol formaldehyde resin, MOE values of 15,589 MPa and MOR values of 26 MPA. Nielsen (1998), studying glued laminated beams produced from 9 years old wood of Eucaliptus grandis, obtained MOE of 10,885 MPa, MOR of $41 \mathrm{MPa}$ and specific density of $0.630 \mathrm{~g} / \mathrm{cm}^{3}$. Therefore, the results of MOE and MOR obtained in Teak wood beams are comparable with the values presented in literature regarding species commercially used for the production of glulam.

Tabela 3. Resultados de ensaios de flexão estática das vigas MLC.

Table 3. Results of static bending tests for glulam beams.

\begin{tabular}{lccc}
\hline Treatment & $\mathbf{A S D}^{\mathbf{1}}\left(\mathbf{g} / \mathbf{c m}^{3}\right)$ & MOE $(\mathbf{M P a})$ & MOR $(\mathbf{M P a})$ \\
\hline $\mathrm{C} 1 / \mathrm{C} 1$ & 0.655 & 11,922 & 66 \\
$\mathrm{C} 2 / \mathrm{C} 2$ & 0.647 & 8,741 & 45 \\
$\mathrm{C} 3 / \mathrm{C} 3$ & 0.590 & 11,007 & 38 \\
$\mathrm{C} 1 / \mathrm{C} 3$ & 0.622 & 13,834 & 83 \\
$\mathrm{C} 1 / \mathrm{C} 2$ & 0.630 & 12,460 & 85 \\
$\mathrm{C} 2 / \mathrm{C} 3$ & 0.616 & 12,454 & 56 \\
Random & 0.621 & 11,340 & 47 \\
Mean & 0.626 & 11,679 & 60.3 \\
\hline
\end{tabular}

$\mathrm{ASD}^{1}$ : apparent specific density of the beams. (MOE e MOR)

Figure 4 shows MOE values for different compositions of glulam based on the three DMOE classes $(\mathrm{C} 1, \mathrm{C} 2$ and $\mathrm{C} 3)$ of the battens.

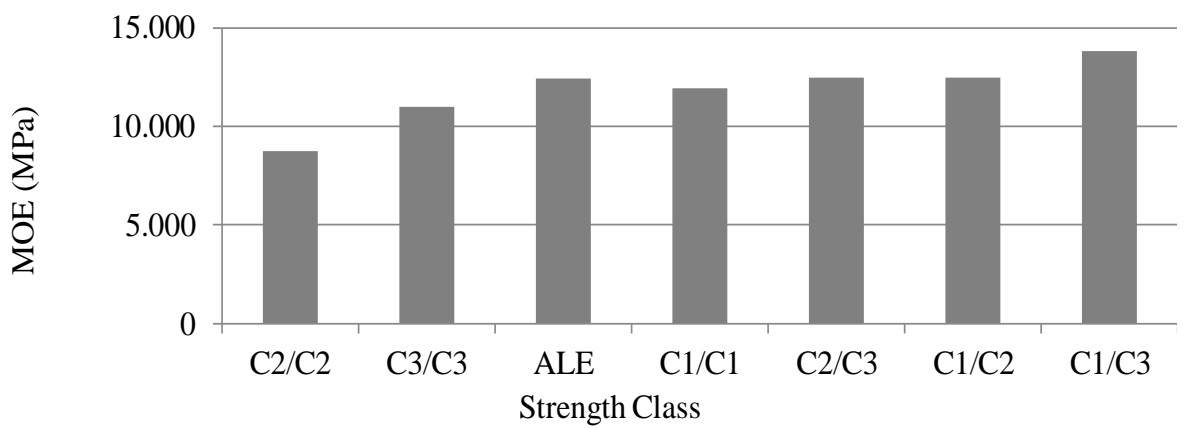

Figura 4. Módulo de elasticidade das vigas de MLC.

Figure 4. Modulus of elasticity of glulam beams.

The lowest MOE values were obtained in the beams composed exclusively with class $\mathrm{C} 2$ $(\mathrm{C} 2 / \mathrm{C} 2)$ and class $\mathrm{C} 3(\mathrm{C} 3 / \mathrm{C} 3)$ battens. Glulam manufactured with class $\mathrm{C} 1$ battens on the faces $(\mathrm{C} 1 / \mathrm{C} 1$, $\mathrm{C} 1 / \mathrm{C} 2$ and $\mathrm{C} 1 / \mathrm{C} 3), \mathrm{C} 2$ on faces and $\mathrm{C} 3$ in the core $(\mathrm{C} 2 / \mathrm{C} 3)$, and also the glulam manufactured with the randomly selected battens (ALE), presented greater MOE values. Inclusion of C2 and C3 parts, with lower DMOE, in the core layers of the glulam did not reduce the MOE values.

Figure 5 shows the MOR values of the different glulam compositions, based on the three DMOE classes (C1, C2 and C3) of the battens.

Beams composed with class $\mathrm{C} 1$ battens on the faces $(\mathrm{C} 1 / \mathrm{C} 1, \mathrm{C} 1 / \mathrm{C} 3, \mathrm{C} 1 / \mathrm{C} 2)$ presented greater MOR values. The distribution of $\mathrm{C} 2$ and $\mathrm{C} 3$ class battens, with lower DMOE, in the core layers in place of $\mathrm{C} 1$ parts, resulted with increased MOR values of the beams, instead of a reduction of this property. This result is very important in the cost benefit ratio considering the possibility to use all the three DMOE classes of battens for the production of glulam.

The smaller MOR values were obtained in glulam composed by $\mathrm{C} 3$ class parts $(\mathrm{C} 3 / \mathrm{C} 3)$, on the faces and core of the beams. Finally, glulam composed by $\mathrm{C} 2$ class parts on faces and core (C2/C2) and 
$\mathrm{C} 2$ on faces and $\mathrm{C} 3$ in the core $(\mathrm{C} 2 / \mathrm{C} 3)$, together with glulam composed by randomly selected parts, presented intermediate MOE values.

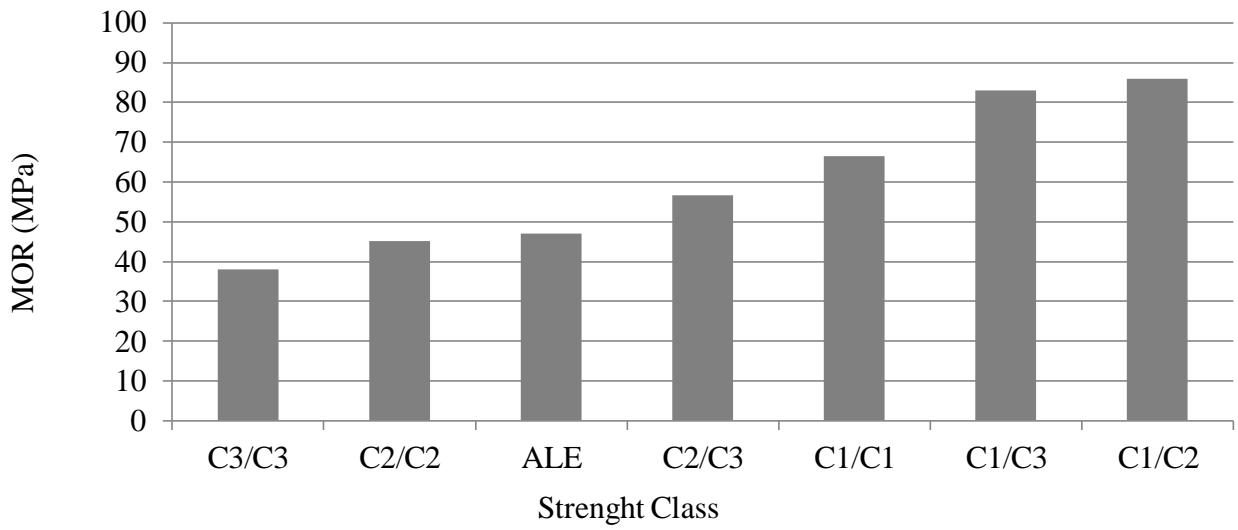

Figura 5. Módulo de ruptura das vigas de MLC.

Figure 5. Modulus of rupture of glulam beams.

\section{Strength of the glue line}

Table 4 shows the results of the shear strength tests of the glue line and the percentage of failures in the wood, obtained from the assessed glulam

Tabela 4. Resultados de resistência da linha de cola das vigas laminadas coladas.

Table 4. Results of glue line strength of glulam.

\begin{tabular}{lccc}
\hline Treatment & Mean $(\mathbf{M P a})$ & CV $(\boldsymbol{\%})$ & Failures $(\boldsymbol{\%})$ \\
\hline $\mathrm{C} 1 / \mathrm{C} 1$ & $13.76 \mathrm{~b}$ & 13.72 & 76.25 \\
$\mathrm{C} 2 / \mathrm{C} 2$ & $10.99 \mathrm{ab}$ & 23.57 & 72.50 \\
$\mathrm{C} 3 / \mathrm{C} 3$ & $9.51 \mathrm{a}$ & 22.39 & 57.50 \\
$\mathrm{C} 1 / \mathrm{C} 3$ & $12.89 \mathrm{ab}$ & 20.30 & 58.75 \\
$\mathrm{C} 1 / \mathrm{C} 2$ & $11.75 \mathrm{ab}$ & 27.52 & 30.00 \\
$\mathrm{C} 2 / \mathrm{C} 3$ & $12.40 \mathrm{ab}$ & 9.90 & 78.57 \\
Random & $13.41 \mathrm{~b}$ & 21.67 & 63.13 \\
\hline
\end{tabular}

The mean values of the shear strength spanned between 9.51 MPa (C3/C3) and $13.76 \mathrm{MPa}$ $(\mathrm{C} 1 / \mathrm{C} 1)$. The greater values were obtained in glulam composed by class $\mathrm{C} 1$ battens on the faces and in the core, and by glulam composed by randomly selected battens, being these statistically equal to glulam made with $\mathrm{C} 2 / \mathrm{C} 2, \mathrm{C} 1 / \mathrm{C} 3, \mathrm{C} 1 / \mathrm{C} 2$ and $\mathrm{C} 2 / \mathrm{C} 3$ classes battens. Glulam made of $\mathrm{C} 3 / \mathrm{C} 3$ resulted in a mean value that was statistically lower compared to means of $\mathrm{C} 1 / \mathrm{C} 1$ and random made. This could be attributed to the effect of the lower specific density and the higher adhesive absorption, which resulted in a "hungry" glue line.

It is worth highlighting the importance of the results obtained in glulam manufactured with randomly selected battens, which under the economical point of view would be profitable, because there is a clear indication that the wood pre-classification operations may not be necessary. Considering the percentage of failures in the wood, except in class $\mathrm{C} 1 / \mathrm{C} 2$ glulam, the mean values were close or above $60 \%$.

The results obtained in this research are matching the values reported in literature, for tests on glulam bonded with phenol-resorcinol-formaldehyde adhesive and made with Pine and Eucalyptus wood. Vital et al. (2006) reported, for Eucalyptus saligna, Eucalyptus grandis and Pinus elliottii, values of shear strength and failure percentages respectively of $9.62 \mathrm{MPa}$ and $29.73 \%, 8.05 \mathrm{MPa}$ and $41.42 \%, 5.63 \mathrm{MPa}$ and 53.25\%. Lima et al. (2008) reported, testing the glue line shear strength in wood from four 
Eucalyptus clones, values of shear strength and failure percentages in the wood that spanned respectively from 7.55 MPa to 9.07 MPa and from $29 \%$ to $64 \%$

\section{CONCLUSIONS}

- Comparative assessments of the results of this work with values reported in the literature for glulam produced from Pine and Eucalyptus species indicated that the use of wood from Tectona grandis in the production of glulam is technically viable.

- The non-destructive classification of battens with the stress waves method showed to be efficient for the composition of glulam made of Tectona grandis wood. The static bending tests demonstrated that the disposition of the battens results into increased MOE and MOR values. It was also confirmed the possibility to implement a balanced composition of glulam using class $\mathrm{C} 2$ and $\mathrm{C} 3$ battens in the internal layers.

- With the exception of the beams assembled with class C3 battens only, which presented lower glue line shear strength, there were no significant differences between the other glulam compositions.

\section{ACKNOWLEDGEMENTS}

The authors sincerely express their appreciation to the company Berneck Painéis e Serrados S.A, in the persons of Mr. Gilson Berneck, Eng. Alfonso Mehl and Fernando Gnoato, for donating the Teak wood used in this work; to Eng. Mario de Andrade, form the company Momentive Química S.A., for donating the adhesives used for the bondage of glulam. To CNPq for giving the financial support to this research.

\section{REFERENCES}

AMERICAN SOCIETY FOR TESTING AND MATERIALS. ASTM D-198. Static tests of timbers in structural sizes. Philadelphia, 1996. 1042 p.

AMERICAN SOCIETY FOR TESTING AND MATERIALS. ASTM D-3110. Standard specification for adhesives used in nonstructural glued lumber products. Philadelphia, 1990. 1042 p.

CUNHA, A. B. Produção de vigas estruturais de madeira avaliadas por meio de ensaios estáticos e dinâmicos. 146 f. Tese (Doutorado em Ciências Florestais) - Universidade Federal do Paraná, Curitiba, 2007.

LIMA, C. K. P.; MORI, F. A.; MENDES, L. M.; TRUGILHO, P. F.; MORI, C. L. S. O. Colagem da madeira de clones de Eucalyptus com três adesivos comerciais. Scientia Forestalis, Piracicaba, v. 36, n. 77, p. $73-77,2008$.

MATOS, J. L. M. Estudos sobre a produção de painéis estruturais de lâminas paralelas de Pinus taeda L. 117 f. Tese (Doutorado em Ciências Florestais) - Universidade Federal do Paraná, Curitiba, 1997.

MELO, R. R.; PAES, J. B.; LIMA, C. R.; FERREIRA, A. G. Estudo da variação radial da densidade básica de sete madeiras do semi-árido. Revista Científica Eletrônica de Engenharia Florestal, Patos, v. 4, n. 7, p. 1 - 8, 2006.

NIELSEN, I. R. Utilização da madeira comercial do híbrido de Eucalyptus urophylla S. T. Blake X Eucalyptus grandis Hill ex Maiden na confecção de vigas laminadas coladas. 109 f. Dissertação (Mestrado em Ciências Florestais) - Universidade Federal do Paraná, Curitiba, 1998.

PIO, N. S. Produção de painéis estruturais de laminas paralelas (PLP) de Eucalyptus grandis Hill ex Maiden.. 174 f. Tese (Doutorado em Ciências Florestais) - Universidade Federal do Paraná, Curitiba, 2002. 
REVISTA DA MADEIRA (REMADE). Características da Teca. Curitiba: Letech Editora e Gráfica, n. 65, 2009. p. 55 - 57.

SILVA, J. C. Caracterização da madeira de Eucalputs grandis Hill ex. Madien, de diferentes idades, visando a sua utilização na indústria moveleira. 160 f. Tese (Doutorado em Ciências Florestais) Universidade Federal do Paraná, Curitiba, 2002.

TRIANOSKI, R. Avaliação da qualidade da madeira de espécies de pinus tropicais por meio de métodos convencionais e não destrutivos. 553 f. Tese (Doutorado em Ciências Florestais) Universidade Federal do Paraná, Curitiba, 2012.

VITAL, B. R.; MACIEL, A. S.; DELLA LUCIA, R. M. Qualidade de juntas coladas com lâminas de madeira oriundas de três regiões do tronco de Eucalyptus grandis, Eucalyptus saligna e Pinus elliottii. Árvore, Viçosa, v. 30, n. 4, p. 637 - 644, 2006. 